\begin{tabular}{|c|c|c|c|}
\hline Case Reports i & \multicolumn{2}{|c|}{ Case Rep Gastroenterol 2015;9:88-92 } & \multirow{3}{*}{$\begin{array}{l}\text { Karger } \\
\text { Open access }\end{array}$} \\
\hline astroenterology & $\begin{array}{l}\text { DOI: } 10.1159 / 000381306 \\
\text { Publisned onIIne: Aprily, } 2015\end{array}$ & $\begin{array}{l}\text { (C) } 2015 \text { S. Karger AG, Basel } \\
1662-0631 / 15 / 0091-0088 \$ 39.50 / 0 \\
\text { www.karger.com/crg }\end{array}$ & \\
\hline & \multicolumn{2}{|c|}{$\begin{array}{l}\text { This is an Open Access article licensed under the terms of the Creative Common } \\
\text { Attribution-NonCommercial } 3.0 \text { Unported license (CC BY-NC) (www.karger.com/OA } \\
\text { license), applicable to the online version of the article only. Distribution permitted for non } \\
\text { commercial purposes only. }\end{array}$} & \\
\hline
\end{tabular}

\title{
Inflammatory Polyp in the Common Bile Duct with Pancreaticobiliary Maljunction
}

\author{
Yuichiro Uchida Yusuke Ome Keita Shimata Yoshio Nagahisa \\ Michio Okabe Kazuyuki Kawamoto Tae Bum Park Tadashi Itoh \\ Keizo Ogasahara
}

Department of General Surgery, Kurashiki Central Hospital, Kurashiki, Japan

\section{Key Words}

Inflammatory polyp $\cdot$ Bile duct polyp $\cdot$ Pancreaticobiliary maljunction

\begin{abstract}
A 63-year-old woman was admitted because of epigastric pain and obstructive jaundice. Endoscopic retrograde cholangiopancreatography and intraductal ultrasonography revealed a $25-\mathrm{mm}$ papillary nodule in the middle to inferior portion of the common bile duct (CBD). Pancreaticobiliary maljunction (PBM) was also identified. Contrast-enhanced computed tomography also showed an enhanced nodule in the CBD, and we suspected intraductal papillary neoplasm of the bile duct. We performed pylorus-preserving pancreatoduodenectomy. Postoperative pathological examination revealed an inflammatory polyp in the middle CBD. Inflammatory polyp in the bile duct is rare and there are no previous reports accompanied by PBM. PBM is a major risk factor for biliary tract cancer. Preoperative diagnosis of a benign disorder was difficult in this case.

(c) 2015 S. Karger AG, Basel
\end{abstract}

\section{Introduction}

The preoperative diagnosis of biliary tumor can be difficult. Biopsy findings by endoscopic retrograde cholangiopancreatography (ERCP) sometimes conflict with the findings of diagnostic imaging. Pancreaticobiliary maljunction (PBM) is a risk factor for biliary tract cancer, the prevalence of biliary tract cancer being 21.6-42.4\% among adult PBM patients [1]. Tumors in the biliary tract in patient with PBM are suggestive of malignancy. In 2010, the clinical entity intraductal papillary neoplasms of the bile duct (IPNB) was defined. IPNB 
Uchida et al.: Inflammatory Polyp in the Common Bile Duct with Pancreaticobiliary Maljunction

has an intraductal papillary growth pattern and includes intraductal papillary cholangiocarcinoma and its precursor lesions [2]. Most previous occurrences of common bile duct (CBD) polyps may now be categorized as IPNB. Surgical resection is recommended for IPNB without distant metastases because it has high malignant potential and often causes recurrent cholangitis and obstructive jaundice. Inflammatory polyps in the bile duct are extremely rare. This report presents the first case of inflammatory polyp in the CBD with PBM.

\section{Case Report}

A 63-year-old woman was admitted to our hospital because of epigastric pain and obstructive jaundice. Contrast-enhanced computed tomography showed a 25-mm enhanced nodule in the middle to inferior portion of the CBD accompanied by proximal dilatation of the bile duct (fig. 1). Tumor markers such as DUPAN-2 and SPAN-1 were increased to 9,700 and $160 \mathrm{U} / \mathrm{ml}$, respectively. Carcinoembryonic antigen and carbohydrate antigen 19-9 were within normal limits. ERCP, intraductal ultrasonography and magnetic resonance cholangiopancreatography (MRCP) revealed that the nodule was papillary, accompanied by PBM (fig. 2). In transpapillary histological biopsy, a papillary structure with edematous interstitial tissue was observed. Plasmacyte and lymphocyte migration was observed, but neoplastic lesions and epithelial dysplasia were not identified. No atypical cells were identified in cytological specimens of bile juice. Considering the findings of PBM, we suspected bile duct neoplasms, including bile duct cancer or IPNB. We performed pylorus-preserving pancreatoduodenectomy (PPPD). Macroscopically, we found a 6-mm polyp in the middle CBD (fig. 3a). Gallstones were not found. Microscopically, we identified a normal ductal structure with multiple plasmacyte migration (fig. 3b). Immunostaining did not show proliferation of p53positive or MIB-1-positive cells. The patient was finally diagnosed with an inflammatory polyp in the CBD accompanied by PBM.

\section{Discussion}

In the biliary tract, gallbladder polyps are common, but CBD polyps are rare. Most CBD polyps have neoplastic changes. Burhans and Myers [3] reported that among 88 cases of extrahepatic bile duct polyps, papilloma was found in 44 cases and adenoma in 39. Those papillomas and adenomas may now be categorized as IPNB.

In the English and Japanese language literature, only five cases of inflammatory polyps in the CBD have been reported (table 1). It is suggested that mechanical stimuli are among the causes of inflammatory polyps in the CBD. T tube placement was done in three cases $[4$, 5]. A CBD stone was found in one case [6], and none of the previous cases had PBM.

PBM is a congenital anomaly in which the main pancreatic duct and CBD converge outside the duodenal wall. PBM is frequently reported in Asian countries and is one of the major causes of biliary tract cancer. The theory of the hyperplasia-dysplasia-carcinoma sequence seems to explain the carcinogenesis of PBM. Pancreatic juice refluxes to the biliary tract and mixes with bile, and the production of cytotoxic substances such as activated pancreatic enzymes occurs. Repeated damage and repair of the biliary mucosa contribute to various gene mutations. This in turn causes histological changes such as hyperplasia, metaplasia and dysplasia, and finally results in biliary carcinogenesis [7, 8]. Once PBM is diagnosed, surgery is recommended, although the type of procedure is controversial [1]. A relationship between 
Uchida et al.: Inflammatory Polyp in the Common Bile Duct with Pancreaticobiliary Maljunction

PBM and IPNB is unclear, but considering the hyperplasia-dysplasia-carcinoma sequence, there may be some correlation.

In our case, we estimated that reflux of pancreatic juice induced inflammation and polyp formation, but there are no reports of inflammatory CBD polyp accompanied by PBM to date. CBD stones or gallstones were not found. We performed PPPD because we suspected bile duct cancer or IPNB. The pathological diagnosis was an inflammatory polyp. Considering that PBM is a risk factor for biliary malignancy, preoperative denial of malignancy was difficult in this case, even though we obtained benign results in preoperative biopsy and cytological specimens.

\section{Disclosure Statement}

The authors have no potential conflicts of interest.

\section{References}

1 Kamisawa T, Ando H, Suyama M, Shimada M, Morine Y, Shimada H; Working Committee of Clinical Practice Guidelines for Pancreaticobiliary Maljunction; Japanese Study Group on Pancreaticobiliary Maljunction: Japanese clinical practice guidelines for pancreaticobiliary maljunction. J Gastroenterol 2012;47:731-759.

2 Bosman FT, Carneiro F, Hruban RH, Theise ND: WHO Classification of Tumours of the Digestive System, ed 4. Lyon, IARC, 2010.

3 Burhans R, Myers RT: Benign neoplasms of the extrahepatic biliary ducts. Am Surg 1971;37:161-166.

-4 Watanabe H, Iwase H, Sugitani M: Inflammatory polyps in common bile duct caused by T-tube. Hepatogastroenterology 2002;49:894-896.

5 Ishimura K, Kondo A, Yachida S, Yonemoto H, Okano K, Kokudo Y, Wakabayashi H, Maeba T: A case of an inflammatory polyp in common bile duct treated by endoscopic polypectomy. Gastroenterol Endosc 1996;38:917-923.

-6 Shepherd HA, Laidlow JM, Ross AP, Vincenti A, Lane RH: Extrahepatic biliary obstruction by a common bile duct inflammatory polyp in association with a gallstone, and treatment by endoscopic sphincterotomy. Endoscopy 1986;18:66-68.

7 Tsuchida A, Itoi T, Aoki T, Koyanagi Y: Carcinogenetic process in gallbladder mucosa with pancreaticobiliary maljunction (review). Oncol Rep 2003;10:1693-1699.

8 Tsuchida A, Itoi T: Carcinogenesis and chemoprevention of biliary tract cancer in pancreaticobiliary maljunction. World J Gastrointest Oncol 2010;2:130-135.

-9 Ro JO: Extrahepatic obstructive jaundice due to inflammatory polyp of common bile duct. Postgrad Med 1975;58:259-260. 
Case Reports in
Gastroenterology

\begin{tabular}{l|l}
\hline \multicolumn{2}{l}{ Case Rep Gastroenterol 2015;9:88-92 } \\
\hline DOI: 10.1159/000381306 & $\begin{array}{l}\text { ○ 2015 S. Karger AG, Basel } \\
\text { www.karger.com/crg }\end{array}$ \\
\hline
\end{tabular}

Uchida et al.: Inflammatory Polyp in the Common Bile Duct with Pancreaticobiliary Maljunction

Table 1. Reported cases of inflammatory polyp in the CBD

\begin{tabular}{lllll}
\hline Reference & $\begin{array}{l}\text { Age (years), } \\
\text { sex }\end{array}$ & Symptom & Complication & Treatment \\
\hline Ro [9] & $55, \mathrm{~m}$ & jaundice & gallbladder stone & polyp resection \\
\hline Shepherd et al. [6] & $84, \mathrm{~m}$ & $\begin{array}{l}\text { pancreatitis, } \\
\text { jaundice }\end{array}$ & CBD stone & $\begin{array}{l}\text { ERCP (sphincterotomy and } \\
\text { stone removal) }\end{array}$ \\
\hline Ishimura et al. [5] & $80, \mathrm{~m}$ & none & $\begin{array}{l}\text { CBD stone, } \\
\text { T tube placement }\end{array}$ & endoscopic resection \\
\hline Watanabe et al. [4] & $27, \mathrm{~m}$ & jaundice & $\begin{array}{l}\text { CBD stone, } \\
\text { T tube placement }\end{array}$ & observation \\
\cline { 2 - 4 } & $73, \mathrm{f}$ & jaundice & CBD stone, & T tube placement \\
\hline Present case & $63, \mathrm{f}$ & jaundice & PBM & observation \\
\hline
\end{tabular}
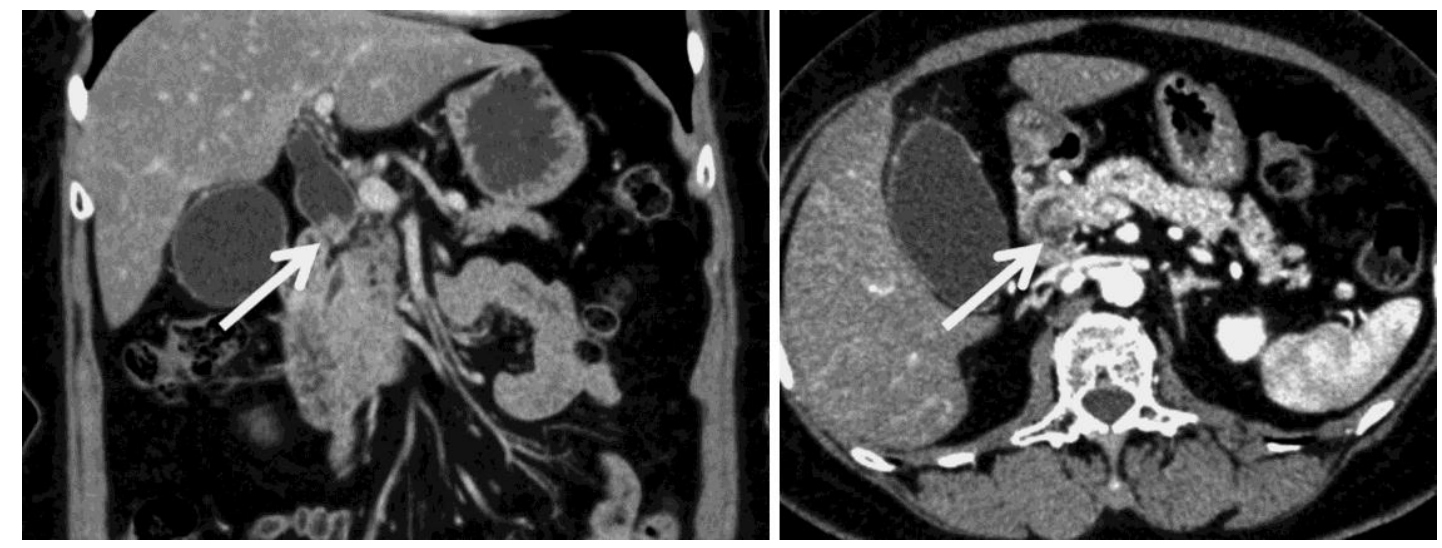

Fig. 1. A 25-mm enhanced nodule (arrow) in the middle to inferior portion of the CBD accompanied by proximal dilatation of the bile duct. 


\section{Case Reports in \\ Gastroenterology}
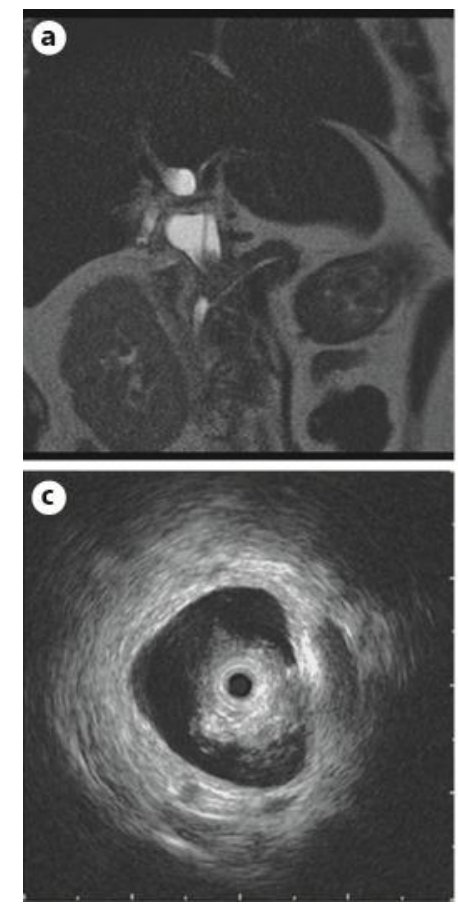

\begin{tabular}{l|l}
\hline \multicolumn{2}{l}{ Case Rep Gastroenterol 2015;9:88-92 } \\
\hline DOI: $10.1159 / 000381306$ & $\begin{array}{l}\text { C 2015 S. Karger AG, Basel } \\
\text { www.karger.com/crg }\end{array}$ \\
\hline
\end{tabular}

Uchida et al.: Inflammatory Polyp in the Common Bile Duct with Pancreaticobiliary Maljunction
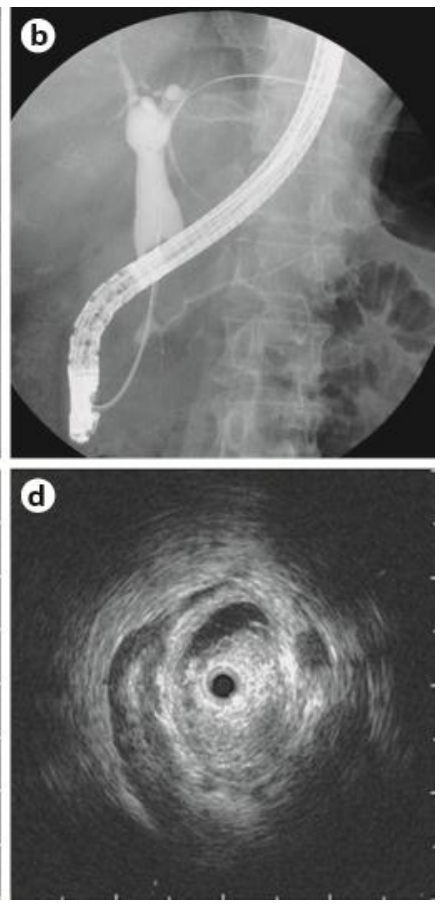

Fig. 2. a, b PBM was identified by MRCP (a) and ERCP (b). c, d Intraductal ultrasonography showed that the nodule was papillary.
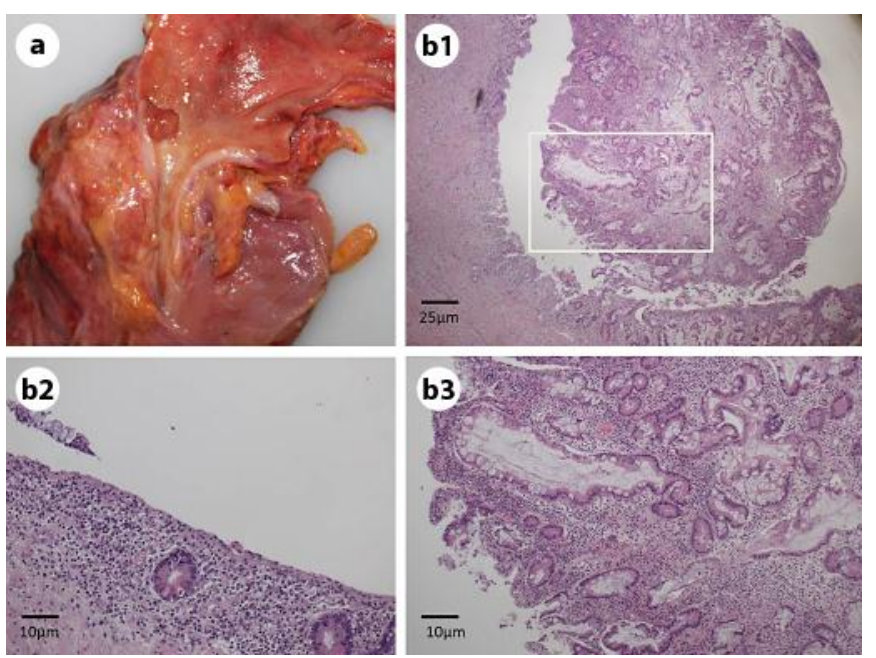

Fig. 3. a A 6-mm polyp in the middle portion of the CBD. b1 Normal ductal structure and multiple plasmacyte migration were identified in the polyp (hematoxylin and eosin staining). b2 No atypical cells were found in the biliary mucosa around the polyp. b3 Enlargement of the inset in b1. b1-b3 Hematoxylin and eosin staining. 